\title{
PERKAWINAN DALAM KITAB SUCI PERJANJIAN LAMA
}

\author{
Surip Stanislaus'
}

\begin{abstract}
Abstrak
Kej 1-3 secara tidak langsung berbicara tentang lembaga perkawinan yang mengatur seksualitas. Lembaga perkawinan itu dipandang sebagai kontrak sipil oleh bangsa Israel (Tob 7:13-14) dengan peran mas kawin (Kej 34:12), tahap-tahap perkawinan (Ul 22:23-27; Kej 24:66-67) dan sifatnya endogen poligam poligini (Ul 7:3-6; 22:28-29). Para nabi menganalogikan lembaga perkawinan itu sebagai hubungan antara Allah dengan umat-Nya, bangsa Israel (Am 3:2; Hos 1; 2; Yer 2:1-3; 3:613; Yeh 16; 23; Yes 54:4-8; 62:4-5). Para bijak Israel meneruskan analogi hubungan Allah-Israel dengan suami-isteri lewat Buku Kidung Agung yang mengangkat kesetaraan derajat laki-laki-perempuan dan memandang positif seksualitas sebagai bagian dari cinta sejati yang tidak dapat dibeli dan yang dibawa mati (Kid 1:13-17; 2:2,7,16; 7:10-11; 8:6-7). Cinta sejati laki-laki dan perempuan itu dijadikan analogi hubungan cinta Allah dengan umat pilihan-Nya (tafsir Yahudi) atau hubungan cinta Kristus dengan Gereja-Nya (tafsir Kristen). Buku Amsal dan Yesus bin Sirakh pun mengisahkan pujian yang mengangkat derajat seorang perempuan dan isteri (Ams 18:22; 19:14; Sir 26:15) serta madah pujian tentang keunggulan dan peran seorang isteri yang baik, berbudi, sopan dan cakap (Ams 31:10-31; Sir 26:1-3,1318).
\end{abstract}

Kata-kata kunci: seksualitas, lembaga perkawinan, kontrak sipil, mas kawin, endogen poligam poligini, analogi, kesetaraan derajat

1 Surip Stanislaus, Lisensiat dalam bidang Theologi Biblis; lulusan Universitas Gregoriana, Roma; Dosen Kitab Suci pada Fakultas Filsafat Unika St. Thomas, Sumatera Utara. 
Apa kata Kitab Suci Perjanjian Lama tentang seksualitas dan perkawinan?

Tulisan ini mau menelusuri dan menangkap signal-signal fundamental dalam Kitab Suci Perjanjian Lama tentang seksualitas dan lembaga perkawinan yang menampungnya.

\section{Buku Kej 1-3}

Versi penciptaan bumi langit dan segala isinya dalam Kej 1:1-2:4a mengisahkan Allah yang menciptakan manusia menurut gambar dan rupa-Nya: "Baiklah Kita menjadikan manusia menurut gambar dan rupa Kita [...] Maka Allah menciptakan manusia ('ādām) itu menurut gambar-Nya, menurut gambar Allah diciptakan-Nya dia; laki-laki dan perempuan diciptakan-Nya mereka" (Kej 1:26-27). Manusia diciptakan Allah dengan seksualitasnya sebagai laki-laki dan perempuan yang saling melengkapi. ${ }^{2}$

Akar kata Ibrani 'ādām berasal dari ' $d m$ yang berarti "merah". Bisa jadi akar kata ini mengacu pada warna kulit yang kemerahmerahan saat manusia dilahirkan. Permainan kata 'ādām (manusia) dan 'ădāmāh (tanah) pun menegaskan bahwa manusia diciptakan dari debu tanah (Kej 2:7). ${ }^{3}$ Jadi, 'ādām berarti manusia baik laki-laki maupun perempuan. Manusia itu satu karena dikatakan dan dipakai kata ganti orang ketiga tunggal: "... menurut gambar Allah diciptakan-Nya dia." Kemudian manusia yang satu itu dijadikan jamak: "laki-laki (zākār)dan perempuan (neqebāh) diciptakan-Nya mereka." Dipakai kata zākār (jenis kelamin laki-laki/maskulin) dan $n^{e} q e b \bar{a}^{h}$ (jenis kelamin perempuan/feminin) dan bukan 'îš (orang laki-laki) dan 'îššâh (orang perempuan) untuk menyatakan bahwa manusia merupakan perpaduan antara laki-laki dan perempuan. Manusia itu bukan laki-laki atau perempuan saja, tetapi dalam dirinya memiliki unsur maskulinitas dan hlm. 60 .

2 G. von Rad, Genesis. A Commentary, OTL (London: SCM Press, 1987),

${ }^{3}$ Manusia itu disebut Adam, karena bertautan dengan kata Ibrani 'ādām dan 'ădāmāh yang artinya debu tanah. [Lihat G. von Rad, Genensis..., hlm. 77]. Kata Ibrani 'ădāmāh adalah kata yang sama dan bergenus feminin dari kata 'ādām yang bergenus maskulin. [Lihat G.J. Wenham, Genesis 1-15, WBC 1 (Nashville: Thomas Nelson Publisher, 1987), hlm. 59; C. Westermann, Genesis 111. A Commentary (London: SPCK, 1984), hlm. 201]. 
feminitas. Persatuan kedua unsur inilah yang menjadikan dirinya gambar Allah. ${ }^{4}$

Perbedaan seks/jenis kelamin laki-laki dan perempuan dikehendaki Allah dan kesetaraan/kesejajaran derajat keduanya ditunjukkan dalam penciptaan pada waktu yang sama, bukan laki-laki dahulu lalu perempuan kemudian, dan tidak ada yang menjadi asal dari yang lain. Perbedaan jenis kelamin/gender dikehendaki Allah dan dimaksudkan untuk saling mengisi dan melengkapi, sehingga saat lakilaki dan perempuan bersatu dalam relasi yang harmonis, mereka menjadi gambar Allah. Sebagaimana Allah kreatif (berdaya cipta) demikian juga persatuan/persetubuhan laki-laki dan perempuan berdaya cipta (melahirkan anak). Dengan demikian gambar dan rupa Allah dalam manusia laki-laki dan perempuan itu dikaitkan dengan berkat perkembangbiakan (prokreasi, berketurunan) dan kuasa atas makhluk-makhluk lain: "Allah memberkati mereka, lalu Allah berfirman kepada mereka: Beranakcuculah dan bertambah banyak, penuhilah bumi dan taklukkanlah itu, berkuasalah atas ikan-ikan di laut dan burung-burung di udara dan atas segala binatang yang merayap di bumi" (Kej 1:28). ${ }^{5}$

Kej 1:28 melukiskan berkat Allah kepada manusia, agar berkembang biak (kreatif melahirkan anak) dan berkuasa atas makhluk ciptaan lainnya. Allah memberkati manusia, yaitu memberi kemampuan untuk prokreasi hingga beranakcucu, menaklukkan bumi dan berkuasa atas makhluk ciptaan lainnya. Berkat itu terungkap dalam kata kerja Ibrani kābas (menaklukkan) dan rādāh (berkuasa). Dalam konteks memeras anggur, kata kerja kābas berarti "menginjak-injak dengan kaki". Dalam konteks berkat (Kej 1:28a), kābas berarti "menaklukkan, menjadikan miliknya, mengolah", seperti ungkapan "mengusahakan dan memelihara" dalam Kej 2:15. Sedangkan kata kerja rādāh berarti "menguasai" seperti seorang raja menguasai bawahannya (bdk. 1Raj 5:4; Yes 14:6). Kata rādāh berasal dari bahasa Akkad redu(m) yang berarti "mendampingi", sehingga dalam konteks berkat (Kej 1:28a) rādāh dapat diartikan sebagai perintah untuk menggembalakan atau mengurus dengan baik makhluk ciptaan lainnya. ${ }^{6}$

4 P. Yasua, Perempuan Sumber Dosa? Sebuah Refleksi Alkitabiah (Malang: Dioma, 2011), hlm. 86-87.

${ }^{5}$ G.J. Wenham, Genesis..., hlm. 33.

6 S. Surip, Harmoni Kehidupan. Asal-usul Alam Semesta. Menggembalakan Ciptaan (Yogyakarta: Kanisius, 2008), hlm. 46. 
Berkat Allah dalam Kej 1:28 itu tidak ada sangkut pautnya dengan "berkat perkawinan" sebagaimana dalam tata cara perkawinan sakramental. Oleh karena itu, Kej 1:26-28 memang berbicara tentang seksualitas dan berkat, tetapi belum berbicara apa-apa mengenai perkawinan.

Versi penciptaan bumi langit dan segala isinya dalam Kej 2:4b-25 mengisahkan Allah yang menciptakan manusia secara hirarkis. Laki-laki diciptakan sebagai yang pertama: "TUHAN Allah membentuk manusia (laki-laki) itu dari debu tanah ${ }^{7}$ dan menghembuskan nafas hidup ke dalam hidungnya..." (Kej 2:7). Namun ternyata laki-laki itu tidak mencukupi untuk dirinya sendiri: “Tidak baik, kalau manusia (laki-laki) itu seorang diri saja. Aku akan menjadikan penolong8 baginya, yang sepadan dengan dia" (2:18). Kata Ibrani kenegdô berasal dari kata $k^{e}$ yang artinya "seperti" dan neged yang berarti "ada di depan". Kata neged pun berakar pada kata kerja bentuk hifil higgîd yang artinya "menyampaikan, menceriterakan". Jadi, penolong yang sepadan adalah penolong yang ada di depannya, yang ada pada tingkat sama, yang setara dengannya, yang dapat diajak berceritera. Penolong yang sepadan adalah teman berbicara, teman berceritera, teman berelasi yang dapat membebaskan dari kesendirian. ${ }^{9}$

Allah pun menciptakan segala binatang dan manusia (laki-laki) itu memberi nama atau berkuasa atasnya, "tetapi baginya sendiri ia

7 Manusia yang dibentuk dari debu tanah senada dengan keyakinan orang Mesir kuno. Orang Mesir menyembah dewa Chnum, yaitu dewa yang digambarkan seperti manusia berkepala kambing. Dewa Chnum inilah yang dipercayai sebagai pencipta tubuh manusia dari debu tanah liat dan menempatkannya dalam kandungan ibunya. [Lihat A. Stoeger, Goot und der Anfang (Múenchen: Verlag J. Pfeiffer, 1964), hlm. 52].

8 Kata Ibrani 'ézer artinya "penolong, pertolongan", yang dalam Perjanjian Lama selalu merujuk pada campur tangan atau pertolongan Allah. [Lihat J.L. Ska, "Je vais lui faire un allie qui soit comme son homologue (Gn 2,18). Á propos du terne 'ezer - aide", dalam Biblica 65 (1984), hlm. 233-238].

9 P. Yasua, Perempuan..., hlm. 159. Teks bukan mengatakan "perempuan adalah penolong laki-laki" karena kata Ibrani 'àdām tidak berarti laki-laki, tetapi manusia (baik laki-laki maupun perempuan). Jadi, Allah membuat bagi manusia (baik laki-laki maupun perempuan) seorang penolong (baik laki-laki maupun perempuan). Baik laki-laki maupun perempuan itu dapat mengalami kesendirian dan dapat menjadi penolong atau teman berbicara bagi lawan jenisnya. 
tidak menjumpai penolong yang sepadan dengan dia" (Kej 2:19-20). Maka, Allah menciptakan seorang perempuan:

21TUHAN Allah membuat manusia (laki-laki) itu tidur nyenyak; ketika ia tidur, TUHAN Allah mengambil salah satu rusuk dari padanya, lalu menutup tempat itu dengan daging. ${ }^{22}$ Dan dari rusuk yang diambil TUHAN Allah dari manusia (lakilaki) itu, dibangun-Nyalah seorang perempuan, lalu dibawa-Nya kepada manusia (laki-laki) itu. ${ }^{23}$ Lalu berkatalah manusia itu: "Inilah dia, tulang dari tulangku dan daging dari dagingku. Ia akan dinamai perempuan, sebab ia diambil dari laki-laki." ${ }^{24}$ Sebab itu seorang laki-laki akan meninggalkan ayahnya dan ibunya dan bersatu dengan isterinya, sehingga keduanya menjadi satu daging. ${ }^{25}$ Mereka keduanya telanjang, manusia dan isterinya itu, tetapi mereka tidak merasa malu.

Allah membuat manusia itu tidur nyenyak, sehingga tidak melihat dan tidak tahu apa yang sedang terjadi. Kata Ibrani tardemāh ${ }^{10}$ yang berarti tidur nyenyak menggarisbawahi ketidaktahuan dan kepasifan manusia dalam penciptaan perempuan. Dengan demikian penciptaan perempuan sepenuhnya karya Allah dan manusia sama sekali tidak terlibat. Sikap tidak sok tahu segalanya dari manusia penting dalam penciptaan penolong yang sepadan demi terbangunnya dialog dan teman berceritera.

Pada waktu manusia tidur nyenyak itu diambilnya salah satu tulang rusuknya dan Allah menjadikannya perempuan. ${ }^{11}$ Perempuan yang diciptakan dari tulang rusuk itu dalam Kej 3:20 diberi nama Hawa yang artinya "ibu semua yang hidup." Jadi, perempuan adalah

${ }^{10}$ Kata Ibrani tardemāh dengan arti yang sama tertemukan juga dalam Kej 15:12; 1Sam 26:12.

11 Penciptaan seorang perempuan dari tulang rusuk tertemukan juga dalam Mitos Dilmun, yaitu mitos bangsa Sumeria dari Mesopotamia bagian selatan. Kisahnya sbb.: Ninhursag adalah dewa kesuburan yang menciptakan seorang anak perempuan untuk menyembuhkan tulang rusuk Engki, dewa pelindung kota Eridu. Anak perempuan itu diberi nama Ninti yang dalam bahasa Sumeria berarti ibu tulang rusuk. Kata Sumeria nin berarti ibu dan $t i$ artinya tulang rusuk. Kata $t i$ juga dapat diartikan membuat hidup, sehingga Ninti berarti ibu kehidupan. [Lihat P. Yasua, Perempuan..., hlm. 163]. 
pembawa kehidupan lewat kelahiran anak dari padanya, sehingga manusia tidak akan punah. Karena tulang rusuk berada dekat hati, maka perempuan yang diciptakan dari tulang rusuk berarti bahwa perempuan itu begitu dekat di hati dan terjalin relasi yang sangat mendalam dengan laki-laki. ${ }^{12}$

Sebenarnya yang jauh lebih penting bukan tulang rusuknya, tetapi kesediaan untuk memberi dan kerelaan untuk kehilangan yang berharga dari dirinya demi mendapatkan penolong yang sepadan. Kesediaan memberi dan tidak sok tahu itulah syarat untuk mendapatkan penolong yang sepadan atau partner berbicara/berdialog. Nah, karena manusia rela memberikan diri dan tidak sok tahu, maka Allah menciptakan perempuan sebagai penolongnya yang sepadan dan membawanya kepada manusia.

Kata Ibrani $b o^{\prime}$ bentuk hifil berarti "membawa, menghantar atau mempersembahkan". Persembahan adalah suatu pemberian atau anugerah. Jadi, Allah yang membawa perempuan kepada manusia mau menggarisbawahi bahwa perempuan merupakan anugerah Allah kepada manusia. Demi memperoleh anugerah dari Allah itulah sering tuntutan kehilangan tulang rusuk atau pemberian/pengorbanan diri tidak menjadi masalah. Ungkapan Allah menghantar perempuan kepada manusia pun bermakna bahwa bukan laki-laki yang mencaricari perempuan, tetapi Allah yang berinisiatif lebih dahulu untuk mempertemukan laki-laki dengan perempuan. Dari makna inilah kiranya jelas bahwa jodoh ada di tangan TUHAN, sehingga menjadi pasangan suami-isteri merupakan panggilan Allah untuk saling mencintai. ${ }^{13}$

Ketika manusia terbangun dari tidurnya dan melihat seorang perempuan yang berada di depannya berkatalah laki-laki itu: "Inilah dia, tulang dari tulangku dan daging dari dagingku." Laki-laki mengakui kesetaraan martabat perempuan itu dengan dirinya dan mengukuhkan adanya relasi kekeluargaan yang sangat erat (bdk. Kej 29:14). Ia berasal dari keluarga yang sama dengan keluarganya atau ia sedarah daging dengan laki-laki (bdk. Kej 29:14-15; Hak 9:2-3; 2Sam 5:1;

12 P. Dacquino, Storia del Matrimonio Cristiano alla Luce della Bibbia (Torino: Elle Di Ci, 1984), hlm. 565; L.A. Mazzinghi - A.J. Bigalli (eds.), Catechesi degli Adulti Attraverso il Libro della Genisi Capitoli 1-11 (Firenze: Arcidiocesi di Firenze, 2002), hlm.37.

${ }^{13}$ P. Yasua, Perempuan..., hlm. 165-166; G.J. Wenham, Genesis..., hlm. 6971. 
19:13-14). Namun dengan mengatakan, "inilah dia, tulang dari tulangku dan daging dari dagingku", laki-laki itu tidak berbicara dengan perempuan itu, tetapi berbicara tentang perempuan itu. Dengan kata lain perempuan itu tidak diperlakukan sebagai subyek atau dengan siapa berbicara atau partnernya berbicara, tetapi sebagai obyek atau tentang apa berbicara atau tentang ia yang adalah tulang dari tulangnya dan daging dari dagingnya. Jadi, manusia yang tertidur nyenyak dan tidak tahu apapun yang terjadi saat perempuan itu diciptakan, kini berlagak sok tahu segala-galanya. Ia tidak bertanya kepada Allah tentang apa yang terjadi saat ia tertidur nyenyak dan mengapa tulang rusuknya hilang, tetapi malah menafsirkan sendiri bahwa perempuan itu tulang dari tulangnya dan daging dari dagingnya. Dengan demikian ia pun mengabaikan campur tangan Allah dan pemberian perempuan sebagai anugerah-Nya. Sikap yang melupakan anugerah dan sok tahu ini merupakan bibit-bibit dosa dari manusia. ${ }^{14}$

Penolong yang sepadan itu diberi nama perempuan karena diambil dari laki-laki. Kata Ibrani untuk laki-laki adalah 'î̌ dan untuk perempuan 'î̌šs̆h Jadi, dalam bahasa Ibrani kesetaraan martabat perempuan dan laki-laki ditunjukkan begitu dekat dengan kata-kata yang bunyinya hampir sama 'îs dan 'î̌šš $\bar{a}^{h}$ (bdk. kata Inggris man dan woman). Namun harus dicatat bahwa penolong yang sepadan itu dinamai perempuan bukan karena berasal dari laki-laki, tetapi karena diambil dari laki-laki atau dibangun dari tulang rusuk manusia. Oleh karena itu, tidak dapat disimpulkan bahwa perempuan lebih rendah dari laki-laki atau perempuan sekunder dan laki-laki primer, sebab ia hanya diambil dan bukan berasal dari laki-laki. Sebaliknya juga tidak dapat dikatakan bahwa perempuan tidak serapuh dan selemah laki-laki, karena ia dibangun dari tulang rusuk dan bukan dari debu tanah. Perempuan memang dibangun dari tulang rusuk yang menjadi simbol kekuatan, tetapi ingat bahwa tulang rusuk manusia itu asalnya dari debu tanah yang merujuk pada kerapuhan dan kelemahan. Jadi, perempuan bukan berasal dari laki-laki, tetapi ambil bagian dalam kekuatan dan kelemahan laki-laki. Tulang sebagai bagian yang kuat dari laki-laki menjadi simbol kekuatan dan daging sebagai bagian yang lembut simbol untuk kerapuhan dan kelemahan. Perempuan menjadi perpaduan kekuatan dan kelemahan laki-laki. ${ }^{15}$

\footnotetext{
14 P. Yasua, Perempuan..., hlm. 166-169.

15 P. Dacquino, Storia..., hlm. 565; P. Yasua, Perempuan..., hlm. 167-168.
} 
Dengan mengatakan bahwa 'î̌š $\bar{a}^{h}$, perempuan, diambil dari ' $\hat{\imath} s$, laki-laki, berarti laki-laki itu tidak rela memberi atau takut kehilangan. Dalam Kej 1:27 tercatat bahwa TUHAN menciptakan 'ādàm, manusia, yaitu laki-laki dan perempuan. Jadi, mengatakan bahwa perempuan diambil dari laki-laki berarti laki-laki mengklaim dirinya sebagai 'ādām, manusia yang lengkap, yaitu laki-laki tanpa kehilangan perempuan. Dengan kata lain laki-laki menjadikan perempuan sebagai bagian dari dirinya atau miliknya yang tidak boleh dihilangkan, karena ia takut kehilangan dan inilah bibit dari dosa manusia. ${ }^{16}$

Laki-laki yang sok tahu segala-galanya, melupakan anugerah dan takut kehilangan itu kini dapat menjalin relasi kasih dengan perempuan. Alhasil, "laki-laki akan meninggalkan ayahnya dan ibunya dan bersatu dengan isterinya, sehingga keduanya menjadi satu daging." Begitu kuatnya daya tarik kodrati yang ditanamkan Allah dalam diri manusia, sehingga laki-laki akan meninggalkan dan memutuskan hubungan atau ikatannya yang paling kuat, yaitu dengan pangkalnya sendiri, ayah dan ibunya. Laki-laki akan meninggalkan kesatuan dengan asalnya, yaitu ayah dan ibunya sebagai implikasi dari keluarga besar, suku dan kelompok sosial asal. Ia akan melepaskan segala afeksi atau ikatan jiwa-raganya untuk membangun ikatan jiwa-raga baru dengan perempuan yang belum banyak berperan dalam hidupnya. Ia akan bersatu dengan perempuan itu sebagai suami-isteri, sehingga jelas bahwa kesatuan sosial mereka berdasarkan perkawinan. Jadi, meninggalkan ayah dan ibunya bukan sekedar soal geografi atau jarak yang memisahkan tempat tinggal, tetapi terlebih soal ketergantungannya sebagai anak, sehingga dapat menjadi laki-laki yang utuh dengan segala kekuatan dan kelemahannya. Hanya dengan demikian ia dapat hidup mandiri, menjalin relasi kasih, bersatu dan menjadi satu daging dengan isterinya. ${ }^{17}$

Laki-laki yang menjadi satu daging dengan istrinya jelas mengacu pada hubungan seks. Hubungan seks itu menghilangkan entitas individual mereka dan menghasilkan entitas individualitas baru yang dwitunggal. Hubungan seks melahirkan entitas sosial baru, yaitu kekerabatan. Alhasil, terbentuklah lembaga perkawinan yang berupa keluarga, marga, suku dan bangsa. Meskipun demikian ungkapan "menjadi satu daging" pertama-tama bukan dimaksudkan dengan hubungan seks atau persetubuhan dan merujuk pada lembaga

\footnotetext{
16 P. Yasua, Perempuan..., hlm. 169.

17 G.J. Wenham, Genesis..., hlm. 70-71.
} 
perkawinan, tetapi lebih pada persatuan pribadi atau kebersamaan. Kata Ibrani bāsār yang berarti "daging, tubuh", bukan lawan dari jiwa sebagaimana paham filsafat Yunani, tetapi pribadi manusia sejauh dipandang dari segi jasmani dan kefanaannya. Arti kata daging jauh lebih luas dari sekedar tubuh manusia, karena mencakup seluruh aspek lahiriah manusia. Menjadi satu daging berarti persatuan pribadi yang tetap otonom sebagai laki-laki dan perempuan hingga sehati dan seperasaan. Persatuan pribadi ini yang dijadikan landasan bahwa perkawinan tidak dapat diceraikan. ${ }^{18}$

Persatuan pribadi suami-isteri itulah yang meskipun mereka telanjang, tetapi mereka tidak merasa malu. Kata Ibrani 'ārom dengan kata bendanya 'erwāh berarti "ketelanjangan" yang merujuk pada kelemahan, kekurangan dan keterbatasan. Ketelanjangan merupakan simbol dari kelemahan, keterbatasan, kekurangan dan kemiskinan, karena orang telanjang tidak memiliki apapun untuk perlindungan dirinya (bdk. Yes 58:7) dan dianggap tidak memiliki harga diri (bdk. Yes 20:1-6; 47:2-3). Dengan demikian ketelanjangan itu memalukan dan mengerikan, karena dapat dimanfaatkan orang lain untuk menghancurkannya. Namun bagi pasangan suami-isteri yang telah menjalin relasi kasih, menerima kekuatan dan kelemahan masingmasing partnernya dan membangun persatuan pribadi, ketelanjangan tidak memalukan dan tidak harus ditutup-tutupi, karena malah dapat dijadikan kesempatan dan peluang untuk saling melengkapi satu sama lain. ${ }^{19}$

Kej 1:26-28 berbicara tentang seksualitas yang terarah pada keturunan atau pembiakan. Sedangkan dalam Kej 2:21-25, hubungan seks antara laki-laki dan perempuan melahirkan kekerabatan, kesetiakawanan, saling melengkapi dan menyempurnakan. Oleh karena itu, Kej 1-2 memberi penilaian sangat positif terhadap seksualitas

18 G.J. Wenham, Genesis..., hlm. 71. Taurat Musa mentolelir dan memberi peluang kepada laki-laki untuk menceraikan isterinya (Kel 24:1-4), tetapi pada akhir abad ke-3 SM berkembang keyakinan bahwa Allah tidak menghendaki bahkan membenci perceraian (Mal 2:14-16). Yesus juga menolak perceraian dan mengingatkan bahwa Musa mengizinkan pemberian surat cerai hanya karena ketegaran hati bangsa Yahudi, dan menegaskan sejak semula Allah tidak menghendaki adanya perceraian berdasarkan ide menjadi satu daging (Mat 19:1-9). Paulus pun menjelaskan sakramentalitas perkawinan berdasarkan persatuan pribadi suami-isteri yang menghadirkan kesatuan Kristus dengan jemaat-Nya sebagai satu tubuh (Ef 5:31-32).

19 P. Yasua, Perempuan..., hlm. 176; G.J. Wenham, Genesis.., hlm. 71-72. 
manusia dan lembaga perkawinan yang menampung seksualitas itu. Sedangkan Kej 3 menampilkan segi negatif dan destruktif tentang seksualitas. Laki-laki dan perempuan yang melalui seksualitas mereka seharusnya dapat saling melengkapi nyatanya malah saling mencelakakan. Perempuan yang lebih dahulu makan buah terlarang, kemudian memberikannya kepada laki-laki agar memakannya juga: "Perempuan itu melihat, bahwa buah pohon itu baik untuk dimakan dan sedap kelihatannya... Lalu ia mengambil dari buahnya dan dimakannya dan diberikannya juga kepada suaminya yang bersamasama dengan dia, dan suaminya pun memakannya" (Kej 3:6). Akibatnya, lewat seksualitasnya laki-laki mendominasi dan membuat perempuan menderita: "Susah payahmu waktu mengandung akan Kubuat sangat banyak; dengan kesakitan engkau akan melahirkan anakmu; namun engkau akan birahi kepada suamimu dan ia akan berkuasa atasmu" (Kej 3:16).

Kej 1:26-28; 2:7,18-25; 3:6,16 berhubungan langsung dengan seksualitas dan hanya secara tidak langsung berbicara tentang lembaga perkawinan yang mengatur seksualitas. Meskipun demikian lembaga perkawinan menjadi sasaran dari Hukum Taurat yang didekatinya bukan secara religius tetapi sipil. Kitab Keluaran, Imamat, Bilangan dan Ulangan menampilkan aneka macam upacara religius, tetapi tidak ada satu pun yang khusus berhubungan dengan perkawinan. Dalam Kej 1:28 Allah memberi berkat, tetapi yang diberkati adalah seksualitas dan tidak dimaksudkan dengan berkat perkawinan. Namun pendekatan sipil Hukum Taurat terhadap lembaga perkawinan itu tidak sama dengan pendekatan profan sekular. Sebab dalam masyarakat tradisional seperti bangsa Israel, religi dan masyarakat melebur jadi satu, sehingga realitas sipil pun memuat dimensi religius. Apalagi Hukum Taurat yang di dalamnya memuat aturan formal tentang lembaga perkawinan dihubungkan dengan Perjanjian antara Allah dan bangsa Israel. Oleh karena itu, dengan menepati dan menghayati seksualitas dalam lembaga perkawinan yang diatur Hukum Taurat berarti bangsa Israel mewujudkan imannya kepada Allah Perjanjian. Dengan demikian lembaga perkawinan pun mendapat dimensi religius dan hubungan suami-isteri terintegrasi ke dalam relasi Allah dengan umat pilihanNya. ${ }^{20}$

${ }^{20}$ Buku Tobit (Tob 7:13-17; 8:4-9) menggambarkan kesatuan religi dan sipil. Pemisahan antara religi dan sipil baru muncul pada abad ke-17 dalam kekristenan. [Lihat C. Groenen, Perkawinan Sakramental. Anthropologi dan Sejarah Teologi, Sistematik, Spiritualitas, Pastoral (Yogyakarta: Kanisius, 1993), hlm. 64]. 
Surip Stanislaus, Perkawinan dalam Kitab Suci Perjanjian Lama

Berikut dipaparkan secara ringkas beberapa point tentang perkawinan yang tersebar dalam buku-buku Perjanjian Lama.

\section{Buku Taurat Musa: Kontrak Sipil}

Dalam buku-buku Taurat Musa tidak tertemukan upacaraupacara religius berkaitan dengan perkawinan, karena perkawinan dipandang sebagai kontrak sipil. ${ }^{21}$ Bangsa Israel memandang perkawinan sebagai kontrak sipil yang disahkan oleh Allah: "TUHAN telah menjadi saksi antara engkau dan isteri masa mudamu yang kepadanya engkau telah tidak setia, pada hal dialah teman sekutumu dan isteri seperjanjianmu" (Mal 2:14 bdk. Ams 2:17). Perjanjian (kata Ibrani berith) artinya kontrak perkawinan yang disahkan dan didukung oleh Allah. ${ }^{22}$ Oleh karena itu, perkawinan dalam Ams 2:17 dipandang sebagai perjanjian Allah dan secara alegoris perjanjian Sinai dalam Yeh 16:8 menjadi kontrak perkawinan antara YHWH dan Israel.

Pandangan perkawinan sebagai kontrak sipil bertahan sepanjang sejarah bangsa Israel, karena sejak buku-buku Taurat Musa disusun secara definitif dan diberlakukan sesudah zaman pembuangan (sekitar tahun $450 \mathrm{SM}$ ) hingga buku Tobit ditulis (sekitar tahun $180 \mathrm{SM}$ ) tidak dikisahkan upacara-upacara religius tentang perkawinan.

Buku Tobit memberikan kesaksian tentang kontrak perkawinan yang dibuat secara tertulis. Dalam Tob 7:13-14 dikisahkan bahwa Raguel menyerahkan Sara kepada Tobia dengan surat perjanjian/kontrak perkawinan.

${ }^{13}$ Lalu Raguel memanggil Sara anaknya dan ia pun datang kepadanya pula. Tangan Sara dipegang oleh Raguel dan demikian Sara diserahkannya kepada Tobia. Dalam pada itu berkatalah Raguel: “Sungguh, sesuai dengan Hukum Taurat ia kupercayakan kepadamu dan seturut ketetapan yang tersurat dalam Kitab Musa kuberikan kepadamu menjadi isterimu. Ambillah dia dan antarkanlah kepada ayahmu dengan sehat

${ }^{21}$ R. de Vaux, Ancient Israel. Its Life and Institutions (London: Darton, Logman \& Todd, 1962), hlm. 33; P. Dacquino, Storia..., hlm. 47.

22 Kata Ibrani berîth atau perjanjian umumnya dikaitkan dengan hal-hal religius, tetapi dalam Mal 2:14 kata berîth dimengerti secara sederhana, yaitu kontrak perkawinan. 
walafiat. Moga-moga Yang Berkuasa di Sorga menganugerahkan damai sejahtera kepada kamu berdua." ${ }^{14}$ Lalu dipanggilnya ibu Sara untuk mengambil sepucuk gulungan. Ditulisnya perjanjian perkawinan dan dengan demikian Sara diserahkannya menjadi isteri Tobia, sesuai dengan ketetapan Taurat Musa.

Di Elefantina, Mesir bagian selatan, tertemukan beberapa kontrak perkawinan orang Israel sejak tahun 600 SM. Rumusan kontrak itu berbunyi: "Dia itu isteri saya dan saya suaminya mulai sekarang dan untuk selama-lamanya." 23

\section{Mas Kawin}

Dalam kontrak perkawinan yang sangat berperan adalah mas kawin, yang disebut mohar: "Walaupun kamu bebankan kepadaku uang jujuran dan uang mahar seberapa banyak pun, aku akan memberikan apa yang kamu minta; tetapi berilah gadis itu kepadaku menjadi isteriku" (Kej 34:12 bdk. Kel 22:16-17; 1Sam 18:25; Ul 22:29). Kata Ibrani mohar sama dengan kata Arab mahar, yang artinya "mas kawin". Namun mohar itu tidak dibayarkan oleh calon suami kepada isteri, tetapi diberikan oleh kelompok/keluarga calon suami kepada kelompok/keluarga calon isteri. ${ }^{24}$

Wujud dari mas kawin itu dapat disepakati oleh kedua belah pihak, yaitu dapat berupa uang, barang dan jasa. ${ }^{25}$ Dalam 1Sam 18:25-27 (bdk. Kej 29:15-30; Yos 15:16; Hak 1:12) dikisahkan tentang kesepakatan

23 R. de Vaux, Ancient..., hlm. 33; P. Dacquino, Storia..., hlm. 50; C. Groenen, Perkawinan..., hlm. 65. Kontrak perkawinan awalnya ditemukan di Mesopotamia dan Undang Undang Hammurabi menyatakan bahwa perkawinan tidak sah jika tidak disertai kontrak secara formal.

${ }^{24}$ R. de Vaux, Ancient..., hlm. 26-29; P. Dacquino, Storia..., hlm. 49; C. Groenen, Perkawinan..., hlm. 66. Kebiasaan yang sama terjadi di Mesir dengan nama mahr dan di Babel yang disebut tirhatu.

25 R. de Vaux, Ancient..., hlm. 26-27; P. Dacquino, Storia..., hlm. 50-51. Dalam Hos 3:2 (bdk. Kej 34:12) wujud mohar berupa uang dan barang: "Lalu aku membeli dia bagiku dengan bayaran lima belas syikal perak dan satu setengah homer jelai." Dalam Kej 29:21 wujud mohar berupa jasa Yakub yang bekerja tujuh tahun bagi Laban: "Sesudah itu berkatalah Yakub kepada Laban: Berikanlah kepadaku bakal isteriku itu, sebab jangka waktuku telah genap, supaya aku akan kawin dengan dia." 
jenis mohar berupa barang yang harus diberikan dan jasa yang harus dilakukan Daud kepada Raja Saul demi mendapatkan Mikhal menjadi isterinya.

25Kemudian berkatalah Saul: "Beginilah kamu katakan kepada Daud: Raja tidak menghendaki mas kawin selain dari seratus kulit khatan orang Filistin sebagai pembalasan kepada musuh raja." [...] 26Ketika para pegawainya memberitahukan perkataan itu kepada Daud, maka setujulah Daud menjadi menantu raja. Waktunya belum genap, 27tetapi Daud sudah bersiap, ia pergi dengan orang-orangnya dan menewaskan dari orang Filistin itu dua ratus orang serta membawa kulit khatan mereka; dan dalam jumlah yang genap diberikan merekalah semuanya itu kepada raja, supaya Daud menjadi menantu raja. Kemudian Saul memberikan Mikhal, anaknya, kepadanya menjadi isterinya.

Lain halnya bila terjadi pemerkosaan dan si pemerkosa terpaksa harus memperisteri perempuan itu (bdk. Kel 22:12). Aturan mohar ditentukan sbb.: "Haruslah laki-laki yang sudah tidur dengan gadis itu memberikan lima puluh syikal perak kepada ayah gadis itu, dan gadis itu haruslah menjadi isterinya, sebab laki-laki itu telah memperkosa dia; selama hidupnya tidak boleh laki-laki itu menyuruh dia pergi" (Ul 22:29).

\section{Tahap Perkawinan}

Tahap pertama dari perkawinan adalah masa pertunangan (kata Ibrani 'araś). Pada tahap ini pasangan saling berjanji yang mengikat dan memberi hak-kewajiban, meskipun mereka belum tinggal serumah (bdk. Ul 22:23-27; 20:7). Ketidaksetiaan pihak perempuan terhadap janji itu dikategorikan zinah dan dikenakan sangsi kepadanya, bahkan hukuman mati (bdk. Ul 22:23-24). Tahap berikutnya, setelah beberapa lama tinggal secara terpisah, mempelai perempuan diantar ke rumah suaminya (bdk. Kej 24:66-67; 29:22; Hak 14:10; Kid 3:6-11; 1Mak 9:39; Tob 8:19b; 10:8). 
Pada malam pertama pertemuan itu mereka tidur bersama dan tahap perkawinan selesai (bdk. Kej 29:23; Tob 8:1-9). ${ }^{26}$

\section{Endogam - Poligam (Poligini)}

Perkawinan bangsa Israel bersifat endogam. Artinya, perkawinan orang di lingkungan kelompoknya sendiri. Awalnya kelompok itu keluarga besar atau marga saja (bdk. Kej 24:4; 28:6; 29:10ii; 20:12; Kel 6:19) dan selanjutnya seluruh bangsa Israel (bdk. Kel 34:15-16; Ul 7:3-6; Yos 23:11-13; Tob 4:12-13). Alasan perkawinan endogam itu awalnya ekonomis dan genealogis, artinya kekayaan harus tinggal dalam kelompok dan demi keturunan yang sesuku (bdk. Bil 27:4; 36:1-9). Perkawinan seperti itu disebut parallel-cousin, artinya orang dikawinkan dengan anak/cucu perempuan saudara ayah atau anak/cucu laki-laki saudara ibu. Misalnya, Abraham kawin dengan adik perempuan seayah tetapi tidak seibu (bdk. Kej 20:12; 2Sam 13:13); ayah Musa kawin dengan saudari ayah atau bibinya (bdk. Kel 6:19). Selanjutnya motivasi endogam itu berkembang terlebih demi kemurnian bangsa dan alasan religius (bdk. Kel 34:15; Ul 7:4; Yos 23:13; Ezr 9:2,12,14; Neh 13:26-27). ${ }^{27}$

Perkawinan bangsa Israel juga poligam yang poligini. Artinya, satu suami banyak isteri dan semua isteri setingkat (bdk. Ul 22:28-29; 21:15). Seorang suami pun secara legal diperbolehkan memiliki gundik (bdk. Hak 19:1-5). Sebab budak perempuan dapat dijadikan gundik bagi tuannya atau anak-anak tuannya (bdk. Bil 31:17-18; Ul 21:10-14; Kel 21:710), tetapi budak seperti itu tidak boleh dijual lagi sebagai budak (bdk. Ul 21:8; Kel 21:14). ${ }^{28}$

${ }^{26}$ R. de Vaux, Ancient..., hlm. 32-34; P. Dacquino, Storia.., hlm. 53; C. Groenen, Perkawinan..., hlm. 66-67. Perkawinan Tobia dan Sara (Tob 8:1), juga Ishak dan Rebeka (Kej 24) merupakan kasus yang tidak mengikuti tahap perkawinan pada umumnya.

27 Struktur sosial bangsa Israel adalah patrilineal, sehingga laki-laki (suami, kepala keluarga) menentukan keturunan dan warisan. Oleh karena itu, isteri pindah dan masuk kelompol suami (Kej 24:58-59). Perkawinan Yakub (Kej 29-30) awalnya ia mengikuti isteri-isterinya, tetapi akhirnya toh isteri-isterinya mengikuti Yakub (Kej 31:17-18,27-30). Perkawinan Simson (Hak 14:8-10; 15:1-2) merupakan kekecualian, karena perkawinan itu bukan di Israel dan tidak terpuji. [Lihat C. Groenen, Perkawinan..., hlm. 67-68].

${ }^{28}$ R. de Vaux, Ancient..., hlm. 24-26; C. Groenen, Perkawinan..., hlm. 6870. 
Beberapa contoh suami yang berpoligini: Abraham beristerikan Sara, tetapi karena lama mandul, Sara seolah-olah meminjam rahim budaknya, Hagar (bdk. Kej 12:5; 16:1-2) dan setelah Sara meninggal, Ketura menjadi isteri Abraham (bdk. Kej 25:1) dan masih ada beberapa gundik Abraham (bdk. Kej 25:6); Yakub beristerikan Rahel dan Lea serta masih ada seorang budak yang menjadi gundik dan satu budak lagi, Bilha (bdk. Kej 30:3); Hakim Gideon beristeri banyak dan memiliki gundik (bdk. Hak 8:30-31); Elkana, ayah Samuel, beristerikan Hana dan Penina (bdk. 1Sam 1:2); Daud beristerikan beberapa orang dan sejumlah gundik (bdk. 2Sam 3:2-5; 5:13; 15:16; 16:21-22); Salomo beristeri dalam jumlah yang sangat besar (bdk. 1Raj 11:1,8); Raja Yoas beristeri dua (bdk. 2Taw 24:3) dan semua raja Israel berpoligini (bdk. 2Taw 11:21; 13:25; 21:14,17; 24:3; 1Raj 20:3-7; 2Raj 23:31,34,36; 24:15).

Hukum Levirat dalam Ul 25:5-10 memaksa orang untuk poligam poligini. Sebab seorang laki-laki, entah sudah beristeri entah belum/tidak, wajib mengawini isteri saudara laki-lakinya yang meninggal tanpa memiliki anak (bdk. Kej 38:8). Kesaksian dari Injil Mrk 12:18-19 mengandaikan bahwa hukum levirat masih berlaku, paling tidak di kalangan kaum Saduki yang berpegang pada hukum itu. Pada prinsipnya poligam diperbolehkan, tetapi karena alasan ekonomi (mas kawin), rakyat biasa lebih banyak monogam. Ishak pun nampaknya monogam (Kej 25:19-21). ${ }^{29}$

\section{Struktur Patriarkhal - Patrilineal}

Bagi bangsa Israel, perkawinan bukan hanya urusan orang yang kawin, tetapi juga perkara kelompok sosial (keluarga, suku) yang bersangkutan. Oleh karena itu, dalam masyarakat Israel yang berstruktur patriarkhal, kepala keluarga, yaitu ayah atau kakek atau (kalau mereka tidak ada) anak laki-laki tertua, mengatur seluruh perkara kelompoknya, termasuk soal perkawinan. Sedangkan pemudapemudi yang mau kawin tidak dimintai pendapat atau persetujuannya. Misalnya, Abraham mencarikan isteri bagi Ishak, anaknya, dan meminta seorang utusan untuk mengatur perkaranya dengan Ribka (Kej 24:33-

29 R. de Vaux, Ancient..., hlm. 37-38; D.L. Christensen, Deuteronomy 21:10-34:12, WBC 6B (Nashville: Thomas Nelson Publisher, 2002), hlm. 605-609. Dari buku-buku Hikmat Kebijaksanaan, kecuali Sir 37:11a, juga ditemukan kesaksian perkawinan yang monogam (Ams 5:15-18; 31:10-31; Pkh 4:9; Sir 26:14). Kisah perkawinan dalam buku Rut (Rut 2:20; 3:9,12-15; 4:14) tidak sepenuhnya sesuai dengan hukum Ul 25:5-10. 
53); Hagar mencarikan isteri bagi Ismael, anaknya (Kej 21:21); Yakub diminta Ishak untuk memperisteri seorang dari anak-anak Laban, keponakannya (Kej 28:1-2); Yehuda mencarikan isteri bagi Er, anak sulungnya, yang bernama Tamar (Kej 38:6). ${ }^{30}$

Bangsa Israel pun berstruktur sosial patrilineal, di mana laki-laki (kepala keluarga, suami) menentukan keturunan dan warisan. Akibatnya, perempuan yang sudah kawin pindah dan masuk ke kelompok suaminya (bdk. Kej 24:58-59; 24:5-8).

Struktur masyarakat patrilineal dan patriarkhal lazimnya juga membuat kedudukan wanita menjadi lemah. Misalnya, dalam hal perkawinan, disamping perceraian/talak hanya hak suami (Ul 24:1), juga hanya isteri mutlak dituntut kesetiaan. Dengan ketidaksetiaannya seorang isteri dapat merusakkan perkawinan sendiri, sebaliknya suami tidak dapat merusakkan perkawinannya sendiri. Seorang suami hanya dapat merusakkan perkawinan suami lain ia berzinah dengan isteri lakilaki lain itu. Jadi, seorang suami dapat memuaskan kebutuhan seksnya dengan perempuan lain, asal perempuan itu tidak bersuami. Penyelewengan suami itu tidak dikenai sangsi atau hukuman, sehingga jelas bahwa hukum perkawinan itu berat untuk perempuan dan ringan untuk laki-laki. Hal ini bukan soal moral/etika, tetapi perkara sosial. Apalagi ketidaksetiaan isteri kepada suami, juga gadis yang masih bertunangan, dapat dikenai hukuman mati (bdk. Im 20:10; Ul 22:20-22; Yer 3:11; Dan 13:23). Memang dalam struktur patrilineal, di mana keturunan dan warisan dihitung menurut garis ayah, harus pasti diketahui siapa anak siapa. Kalau isteri tidak setia kepada suami, maka kepastian hilang, karena orang tidak tahu lagi siapa ayah dari anak yang akan dilahirkan perempuan itu. Dengan demikian otomatis perempuan pun tidak memiliki hak atas warisan, entah dari ayah atau suami, kecuali ia anak tunggal (bdk. Bil 27:8; 36). Seorang perempuan juga dianggap lebih rendah dari pada seorang laki-laki (bdk. Im 27:3-7). Meskipun demikian dalam buku-buku Hikmat Kebijaksanaan ada juga pujian terhadap seorang perempuan dan isteri (bdk. Ams 12:4; 18:22; 19:14; 31:10ii; Sir 26:1-4,13-18; 36:21-24). ${ }^{31}$

\footnotetext{
${ }^{30}$ C. Groenen, Perkawinan..., hlm. 65-66.

${ }^{31}$ C. Groenen, Perkawinan..., hlm. 72.
} 


\section{Hukum Talak dan Surat Cerai}

Perceraian atau talak tidak dianjurkan, tetapi faktanya perceraian terjadi dan ada hukum yang secara eksplisit mengaturnya, yaitu Ul 24:14. Ul 22:19,28-29 dan Im 22:13 (bdk. Hos 3:1-3; Mal 2:13-16; Yer 3:1,8; Yes 50:1) mengandaikan sudah ada praktek talak di kalangan orang Israel dan menyengsarakan kaum perempuan yang ditalak, sehingga Musa memberikan peraturan dalam Ul 24:1-4.

${ }^{1}$ Apabila seseorang mengambil seorang perempuan dan menjadi suaminya, dan jika kemudian ia tidak menyukai lagi perempuan itu, sebab didapatinya yang tidak senonoh dari padanya, lalu ia menulis surat cerai dan menyerahkannya ke tangan perempuan itu, sesudah itu menyuruh dia pergi dari rumahnya, ${ }^{2}$ dan jika perempuan itu keluar dari rumahnya dan pergi dari sana, lalu menjadi isteri orang lain, ${ }^{3}$ dan jika laki-laki yang kemudian ini tidak cinta lagi kepadanya, lalu menulis surat cerai dan menyerahkannya ke tangan perempuan itu serta menyuruh dia pergi dari rumahnya, atau jika laki-laki yang kemudian mengambil dia menjadi isterinya itu mati, ${ }^{4}$ maka suaminya yang pertama, yang telah menyuruh dia pergi itu, tidak boleh mengambil dia kembali menjadi isterinya, setelah perempuan itu dicemari; sebab hal itu adalah kekejian di hadapan TUHAN.

Ul 24:1-4 diberikan oleh Musa bukan untuk mengesahkan perceraian, tetapi membatasi akibat-akibat negatif dari tindakan para suami yang tidak bertanggungjawab terhadap isterinya. Musa bukan mengizinkan perceraian, tetapi melarang laki-laki menikahi lagi isteri yang diceraikannya kalau isteri itu sudah menikah lagi dengan laki-laki lain. Jadi, teks itu sudah mengandaikan adanya perceraian dan hanya menentukan formalitas hukum demi melindungi perempuan dari ketidakadilan. Karena betapa malangnya isteri yang diceraikan dan demi belaskasih terhadapnya, Musa menyuruh memberi surat cerai. Oleh karena itu, dalam Mat 19:8 Yesus mengatakan: "Karena ketegaran hatimu Musa mengizinkan kamu menceraikan isterimu, tetapi sejak semula tidaklah demikian." 32 Musa mengizinkan perceraian karena

32 Yesus menolak tegas dispensasi yang diberikan Musa dan memaparkan perkawinan yang dikehendaki Allah dengan mengutip Kej 1:27 
dipaksa kaum laki-laki Israel yang telah berdosa dan toleran terhadap tindakan-tindakan salah mereka. Toleran itu bukan berarti bahwa Musa membenarkan tindakan salah mereka, melainkan untuk mengatasi ketegaran hati orang Israel, membatasi praktek kejahatan dan melindungi kaum perempuan dari akibat buruk penceraian. ${ }^{33}$

Bagi bangsa Israel hanya suami memiliki hak talak. Hanya suami bisa menceraikan isterinya dan isteri tidak punya hak talak. Ul 24:1 mengindikasikan bahwa tidak ada instansi lain yang berhak campur tangan, tetapi hanya suami wajib menuliskan surat talak. Artinya, hanya suami berhak menuliskan surat talak dan dengan surat itu isteri memiliki bukti bahwa ia tidak bersuami lagi, sehingga bisa diperisteri orang lain. Isteri yang sudah ditalak bisa kembali ke kelompok asalnya (Im 22:13) dan dapat rujuk kembali. Maka, talak baru betul-betul definitif bila perempuan itu sudah diperisteri oleh laki-laki lain (bdk. Ul $24: 4) \cdot{ }^{34}$

Dibanding dengan bangsa Mesopotamia dan Mesir yang memberikan hak talak kepada isteri dan melindunginya, hukum talak Israel memang lebih sewenang-wenang. Mungkin kecendurungan suami bertindak semaunya sendiri itu yang kemudian hari menuai protes: "Aku membenci perceraian, [...] Maka jagalah dirimu dan janganlah berkhianat!" (Mal 2:16). Akibatnya, larangan perceraian itu

dan 2:24. Dengan tegas Ia mengatakan: "Apa yang telah dipersatukan Allah, tidak boleh diceraikan manusia."

33 R. de Vaux, Ancient..., hlm. 34-35. Pada zaman Yesus persoalan perceraian menjadi perdebatan sengit antara diri-Nya dengan orang-orang Farisi. Perdebatan itu dipicu oleh tafsir yang berbeda tentang kata "tidak senonoh" dalam Ul 24:1 sebagai alasan penceraian. Rabi Syammai berpendapat bahwa "tidak senonoh" berkaitan dengan sesuatu yang memalukan secara moral, terutama perzinahan. Rabi Hillel menafsir lebih longgar dan luas sekali hingga hal-hal sepele, seperti memecahkan piring makan, berbicara dengan laki-laki asing, berkata tidak sopan tentang hubungan dengan suaminya dan cerewet. Dengan demikian perceraian bisa terjadi karena alasan-alasan yang sangat sepele, bahkan tanpa alasan.

${ }^{34}$ R. de Vaux, Ancient..., hlm. 34-35; D.L. Christensen, Deuteronomy..., hlm. 566-568; C. Groenen, Perkawinan..., hlm. 70-71. Berkaitan dengan format surat cerai, Hos 2:1 memberi signal, yaitu pernyataan dari pihak suami yang membatalkan kotrak perkawinan: "Dia bukan isteriku dan Aku ini bukan suaminya". Di Elefantina tertemukan format surat cerai yang bunyinya sbb.: "I divorce my wife" (harfiahnya: I hate my wife). Bdk. format surat cerai di Asyur: "I repudiate her" atau "You are no more my wife." 
dipandang sebagai makruh (tidak terpuji) saja. Artinya, Allah mencela perceraian, tetapi kalau dilakukan pun tidak ada hukumannya. ${ }^{35}$

\section{Buku Nabi-nabi: Analogi Allah-Israel dengan Suami-Isteri}

Para nabi memakai lembaga perkawinan sebagai analogi hubungan antara Allah, YHWH, dengan bangsa Israel, umat-Nya. Untuk pertama kalinya analogi itu diungkapkan secara sama-samar oleh Nabi Amos: "Hanya kamu yang Kukenal dari segala kaum di bumi, sebab itu Aku akan menghukum kamu, karena segala kesalahanmu" (Am 3:2). Kata kerja mengenal berarti "memiliki hubungan pribadi yang intim, memilih dengan cinta, mengasihi atas dasar pengalaman". ${ }^{36} \mathrm{Nabi}$ Hosea mengembangkan pemikiran itu berdasarkan pengalamannya sendiri dalam hidup perkawinan, yaitu meskipun isterinya berzinah dan meninggalkannya tetapi ia tetap mengasihinya (bdk. Hos 1:2-9; 2:1,6,1315,22; 3:1-3). Dari pengalaman pribadi itu Hosea ambil bagian dalam perasaan Allah terhadap Israel yang tidak setia tetapi Allah tetap mengasihi umat-Nya itu. Hos 1-2 melukiskan hubungan Allah-Israel seperti hubungan suami-isteri. ${ }^{37}$

Selanjutnya pemikiran analogis itu diikuti oleh Yeremia (Yer 2:13; 3:6-13), Yehezkiel (Yeh 16; 23) dan Deutero Yesaya (Yes 54:4-8; 62:4-5). Nabi Yeremia melukiskan bahwa dosa bangsa Israel terhadap Allah bagaikan ketidaksetiaan seorang isteri kepada suaminya yang telah mengasihinya dengan sederet kebaikan (Yer 2:1-3,23-25,29-37; 3:1-5,613). Dalam Yer 3:6-13 Kerajaan Utara (Israel) dan Kerajaan Selatan (Yehuda) diibaratkan dengan dua saudara perempuan yang menjadi isteri Allah. Sang kakak/Israel tidak setia kepada Allah, maka ia

35 R. de Vaux, Ancient..., hlm. 35-36. Larangan talak dalam Mal 2:16 didasarkan pada Kej 2:24, namun sulit dibuktikan bahwa Kej 2:24 mendukung monogami dan melarang talak. Ketidaktegasan larangan talak pun berakibat buruk terhadap penghargaan kaum perempuan dan praktek talak tetap berlangsung sebagaimana nampak dalam Sir 25:24-26 yang menyatakan: "Permulaan dosa dari perempuan dan karena dialah kita sekalian mesti mati. Jangan membiarkan air meluap, dan jangan pula membiarkan isteri yang jahat berleluasa. Jika ia tidak berjalan menurut tuntunanmu, pisahkanlah dari tubuhmu."

${ }^{36}$ P. Dacquino, Storia..., hlm. 54-55.

37 L.A. Schökel, I Nomi dell'Amore. Simboli Matrimoniali nella Bibbia (Casale Monferrato: Piemme, 1997), hlm. 158-165; J.J. Mays, Hosea. A Commentary, OTL (London: SCM Press, 1969), hlm. 21-53. 
diceraikan dan tahun 722 SM dihancurkan musuh/Asyur. Sang adik/Yehuda pun tidak mau belajar dari kakaknya dan lebih mengikuti kekasihnya/dewa-dewa asing, sehingga di tahun $587 \mathrm{SM}$ juga dihancurkan musuh/Babel. Meskipun demikian karena kasih Allah tiada berubah dan Yeremia menubuatkan bahwa pada masa mendatang Israel akan menjadi isteri yang setia lewat perjanjian baru dan kekal dengan Allah (Yer 31:31-34). ${ }^{38}$

Nabi Yehezkiel mengulas secara panjang lebar analogi hubungan suami-isteri antara Allah dan kerajaan Israel-Yehuda itu sejak Exodus hingga pembuangan dan perbudakan mereka di Asyur-Babel dengan bahasa yang amat erotis dalam Yeh 16 dan 23. Pembuangan dan perbudakan merupakan hukuman atas ketidaksetiaan Israel-Yehuda terhadap Allah, tetapi penolakan Allah dalam Yeh 16:59-63 sifatnya tidak definitif dan Allah akan tetap mengasihinya: "Aku akan mengingat perjanjian-Ku dengan engkau pada masa mudamu dan Aku akan meneguhkan bagimu perjanjian yang kekal" (Yeh 16:60). ${ }^{39}$

Nabi Deutero-Yesaya melukiskan bahwa pembuangan dan perbudakan itu hanya hukuman sementara. Dalam Yes 54:4-8 menggambarkan secara analogis hubungan Allah-Israel dengan suamiisteri yang murka sesaat karena ketidaksetiaan tetapi akur/bersatu kembali karena kasih setia abadi:

4Janganlah takut, sebab engkau tidak akan mendapat malu, dan janganlah merasa malu, sebab engkau tidak akan tersipu-sipu. Sebab engkau akan melupakan malu keremajaanmu, dan tidak akan mengingat lagi aib kejandaanmu. 5Sebab yang menjadi suamimu ialah Dia yang menjadikan engkau, TUHAN semesta alam nama-Nya; yang menjadi Penebusmu ialah Yang Mahakudus, Allah Israel, Ia disebut Allah seluruh bumi. ${ }^{6}$ Sebab seperti isteri yang ditinggalkan dan yang bersusah hati TUHAN memanggil engkau kembali; masakan isteri dari masa muda akan tetap ditolak? firman Allahmu. ${ }^{7}$ Hanya sesaat lamanya Aku meninggalkan engkau, tetapi karena kasih sayang yang besar Aku mengambil engkau kembali.

38 L.A. Schökel, I Nomi..., hlm. 165-170; R.P. Carroll, Jeremiah. A Commentary, OTL (London: SCM Press, 1986), hlm. 118-121, 144-148, 609-614.

39 L.A. Schökel, I Nomi..., hlm. 170-176; W. Eichrodt, Ezekiel. A Commentary, OTL (London: SCM Press, 1970), hlm. 196-220, 317-334. 
${ }^{8}$ Dalam murka yang meluap Aku telah menyembunyikan wajah$\mathrm{Ku}$ terhadap engkau sesaat lamanya, tetapi dalam kasih setia abadi Aku telah mengasihani engkau, firman TUHAN, Penebusmu.

Analogi hubungan YHWH-Israel seperti suami-isteri mengungkapkan hubungan personal atas dasar kasih dari hati. Sebagai suami, Allah diperkenalkan dengan pribadi yang sungguh terlibat dan peduli terhadap kekasih-Nya, juga pribadi yang kecewa dan murka karena ketidaksetiaan manusia. Meskipun demikian kasih Allah itu melampaui segala balasan yang tidak memadai dari manusia, sehingga hukuman yang diberikan bukan berarti penolakan untuk selamanya, tetapi lebih sebagai pendidikan untuk menuju pertobatan dan perbaikan. ${ }^{40}$

Analogi hubungan Allah-Israel dengan suami-isteri lebih bernuansa negatif, yaitu ketidaksetiaan bangsa Israel kepada Allah-Nya, karena asal-usulnya dari pengalaman negatif hidup perkawinan Nabi Hosea. Latar belakang pelacuran dan perzinahan dari isteri Hosea juga menjadi dasar pemikiran ketidaksetiaan Israel kepada Allahnya dengan menyembah dewa-dewi itu disebut zinah. Istilah zinah merujuk pada ketidaksetiaan isteri kepada suaminya yang menuntut kesetiaan ekslusif. ${ }^{41}$

Analogi hubungan Allah dengan Israel berlatarbelakang struktur perkawinan patrilineal. Seperti seorang calon suami yang memilih calon isterinya dan calon isteri hanya perlu menyetujuinya, pun suami menjadi kepala keluarga dan tuan atas isterinya, juga isteri dituntut kesetiaan mutlak kepada suami dan hanya suami memiliki hak talak; demikian halnya Allah yang memilih umat-Nya dan Israel harus menyetujuinya, pun Allah menjadi TUHAN atas bangsa Israel, juga Israel wajib setia kepada Allah dan Allah saja dapat menceraikan Israel. Maka, analogi ini jelas kurang tepat bila dikenakan pada struktur perkawinan matrilineal atau partnership. Dalam analogi pun muncul kata seperti kasih setia, mencintai, kasih sayang (bdk. Hos 2:18; 3:1; Yes 54:7-8; Yer 2:2; Yeh 16), tetapi kata-kata itu dapat diproyeksikan ke analogi cinta nabsu seksual. Akibatnya kasih Allah kepada umat dapat

40 L.A. Schökel, I Nomi..., hlm. 180-183; C. Westermann, Isaiah 40-66. A Commentary, OTL (London: SCM Press, 1969), hlm. 269-276.

${ }^{41}$ C. Groenen, Perkawinan..., hlm. 74-75. 
disalahartikan sebagai kasih yang tanpa dasar atau prakarsa apa pun dari pihak Israel, yaitu Allah begitu saja memilih Israel menjadi umatNya dan tetap setia pada pilihan-Nya (bdk. Ul 7:6-10; Yes 63:7-8; Yeh 16:6-14; Mal 1:2). Kasih umat kepada Allah pun dapat disalahartikan sebagai kewajiban untuk mentaati perintah-perintah-Nya saja dan harus menyembah satu Allah itu (bdk. Ul 6:4-9; 7:11; 30:6-8,16). ${ }^{42}$

\section{Buku Hikmat Kebijaksanaan: Analogi dan Kesetaraan Derajat}

Buku Kidung Agung meneruskan analogi hubungan Allah-Israel dengan suami-isteri. ${ }^{43}$ Buku Kidung Agung mengetengahkan kesetaraan laki-laki dan perempuan yang saling menghargai dan mencintai satu sama lain. Hubungan cinta yang saling mengangkat dan menghargai pribadi itu dijadikan analogi hubungan cinta Allah dengan umat pilihan-Nya (tafsir Yahudi) atau hubungan cinta Kristus dengan GerejaNya (tafsir Kristen).

42 Analogi yang bersifat negatif dan potensial disalahartikan itu kiranya yang juga mempengaruhi Kitab Suci Perjanjian Baru untuk tidak meneruskan cara pikir yang sama. Oleh karena itu, dalam Ef 5:22-33 Paulus justru membalikkannya, di mana hubungan Kristus-Gereja harus menjadi contoh hubungan suami-isteri:

${ }^{22} \mathrm{Hai}$ isteri, tunduklah kepada suamimu seperti kepada Tuhan, ${ }^{23}$ karena suami adalah kepala isteri sama seperti Kristus adalah kepala jemaat. Dialah yang menyelamatkan tubuh. ${ }^{24}$ Karena itu sebagaimana jemaat tunduk kepada Kristus, demikian jugalah isteri kepada suami dalam segala sesuatu. ${ }^{25} \mathrm{Hai}$ suami, kasihilah isterimu sebagaimana Kristus telah mengasihi jemaat dan telah menyerahkan diri-Nya baginya ${ }^{26}$ untuk menguduskannya, sesudah Ia menyucikannya dengan memandikannya dengan air dan firman [...] ${ }^{32}$ Rahasia ini besar, tetapi yang aku maksudkan ialah hubungan Kristus dan jemaat [...].

Dengan demikian Paulus mau menggambarkan cita-cita perkawinan kristiani, yaitu persatuan kasih suami-isteri seperti persatuan Kristus-Gereja. Kitab Wahyu pun menegaskan bahwa Gereja itulah pengantin perempuan, mempelai Anak Domba (Why 19:7; 21:2,9) yang selalu mendambakan kedatangan Kristus (Why 22:17).

43 Ulasan tentang Buku Kidung Agung sepenuhnya diangkat dari artikel S. Surip, "Makna di Balik Kisah Kasih Sejati dalam Buku Kidung Agung", pada buku bungai rampai Jarot Hadianto, (ed.), Keluarga Bersekutu dalam Sabda (Jakarta: LBI, 2013), hlm. 23-46. 
Bangsa Israel dengan struktur patriarkhalnya selalu mendahulukan atau mengutamakan kaum laki-laki. Dalam hal percintaan pun laki-laki harus menyatakan cintanya lebih dahulu dan jawaban perempuan menyusul atau malah dianggap tidak perlu dijawab dan tinggal menyetujui. Buku Kidung Agung mengkritisi tradisi Israel itu dan mengedepankan kesetaraan laki-laki dan perempuan sebagai manusia sederajat yang saling mencintai dan memuji keindahan masing-masing pribadi. Dengan mesranya si gadis dipanggil dinda (7 kali), manisku (9 kali) dan pengantin perempuan (6 kali); sebaliknya sang jejaka dipanggil dengan kekasihku (31 kali) dan jantung hatiku (5 kali). Si gadis dipuji karena cantik dan jelita (Kid 4:112; 6:4-7; 7:1-9); sebaliknya sang jejaka dipuja karena tampan (Kid 1:16). Memang sang jejaka lebih sering memuji si gadis, tetapi besarnya kerinduan si gadis membuatnya berulang-ulang mencari sang jejaka (Kid 3:1-3; 5:6; 6:1). Buku Kidung Agung pun dibuka (Kid 1:2-8) dan ditutup (Kid 8:10-12,14) dengan sosok dan pembicaraan tentang si gadis sebagai bentuk perhatian dan perhargaan terhadap kaum perempuan di dunia yang berlatar belakang patriarkhal.

Buku Kidung Agung melukiskan kisah kasih sepasang manusia yang saling menghargai dan memuji dengan tulus, yaitu si gadis Sulam dan sang gembala. Si gadis Sulam mengibaratkan sang gembala, kekasihnya: "Bagiku kekasihku bagaikan sebungkus mur, tersisip di antara buah dadaku" (Kid 1:13). Sebaliknya sang gembala mengibaratkan si gadis Sulam, kekasihnya: "Bagiku kekasihku setangkai bunga pacar di kebun-kebun anggur En-Gedi" (Kid 1:13-14).

Sang gembala membandingkan si gadis Sulam dengan "bunga pacar" yang disukai lebah dan serangga lainnya. Bunga pacar tidak gampang tumbuh di tanah kering, tetapi sang gembala mengatakan bahwa bunga itu tumbuh di kebun-kebun anggur En-Gedi, daerah padang gurun di sebelah barat Laut Mati. Daerah En-Gedi atau Ein Gedi terkenal dengan oasis atau mata air di padang gurunnya, tetapi sebagian besar tanahnya kering dan cuacanya panas. Artinya, bunga pacar yang tumbuh di padang gurun itu sangat istimewa, apalagi bagian-bagian dari tanaman itu bisa dijadikan obat tradisional. Maka bagi sang gembala, si gadis Sulam itu sangat istimewa, luar biasa, obat dan penyejuk panas-keringnya gairah cintanya. Hal ini secara alegoris mau menganalogikan Allah yang jatuh cinta kepada bangsa Israel, sehingga menjadikannya sebagai umat pilihan-Nya: "Bukan karena lebih banyak jumlahmu dari bangsa mana pun juga, maka hati TUHAN terpikat olehmu dan memilih kamu... tetapi karena TUHAN mengasihi kamu dan memegang sumpah-Nya yang telah diikrarkannya kepada nenek 
moyangmu" (U1 7:7-8). Dalam suratnya kepada Titus, Paulus berkata: "Dia telah menyelamatkan kita, bukan karena perbuatan baik yang telah kita lakukan, tetapi karena rahmat-Nya oleh permandian kelahiran kembali dan oleh pembaharuan yang dikerjakan oleh Roh Kudus" (Tit 3:5).

Si gadis Sulam pun membandingkan sang gembala dengan "sebungkus mur" yang sangat berharga dan menyenangkan. Mur adalah wangi-wangian yang terbuat dari getah harum pohon mur. Mur termasuk langka di Palestina dan diimport dari daerah Arab, sehingga mahal harganya. Mur biasanya dikemas dalam bungkusan kain atau pundi-pundi, sehingga bisa diselipkan di antara buah dada sebagai pewangi. Oleh karena itu, "tersisip" bisa diartikan tinggal, menginap, berbaring. Maka bagi si gadis Sulam, sang gembala selalu tinggal di hatinya dan membuat dirinya senang, semangat dan tidak pernah kesepian. Hal ini secara alegoris mau menganalogikan Allah yang tinggal di tengah-tengah umat pilihan-Nya, yaitu dalam Tabut Perjanjian di Bait Allah Yerusalem. Jadi, "bagiku” merujuk pada umat Israel yang sedang berbicara; "kekasihku" adalah YHWH, TUHAN Allah Israel satu-satunya; "tersisip" berarti tinggal dalam Tabut Perjanjian di Bait Allah Yerusalem; "di antara buah dadaku" mengacu pada Kerajaan Utara (Israel) dan Kerajaan Selatan (Yehuda) yang duaduanya merupakan daerah pegunungan, dan letak Yerusalem lebih kurang di perbatasan kedua kerajaan itu.

Sementara itu di kalangan umat Gereja Kristen berkembang penafsiran yang mengenakan "sebungkus mur" pada Yesus Mesias yang menderita. Sebab sewaktu Yesus akan dimakamkan ada disertakan campuran minyak mur dengan minyak gaharu (Yoh 19:39). Sedangkan "buah dada" merujuk pada Kitab Suci Perjanjian Lama (yang berisi nubuat tentang penderitaan Yesus) dan Kitab Suci Perjanjian Baru (yang berisi kesaksian tentang penderitaan Yesus). Jadi, "bagiku" berarti umat Gereja Kristen yang sedang berbicara; "kekasihku bagaikan sebungkus mur" adalah Yesus Mesias yang menderita; "tersisip di antara buah dadaku" merujuk pada Kitab Suci Perjanjian Lama dan Perjanjian Baru. "Buah dada" juga bisa diartikan dengan dua hukum kasih (kasih kepada Allah dan kasih kepada sesama) yang menjadi inti Decalog atau Sepuluh Perintah Allah. Menurut bangsa Israel, pembagian Decalog itu bukan perintah satu-tiga dan empat-sepuluh, tetapi satu-lima (kasih kepada Allah) dan enam-sepuluh (kasih kepada sesama); perintah yang sama banyaknya seperti dua buah dada yang sama besarnya. 
Dalam Kidung Agung kemudian sang gembala memuji si gadis Sulam, kekasihnya: "Lihatlah, cantik engkau, manisku, sungguh cantik engkau, bagaikan merpati matamu" (Kid 1:15). Sang gembala memuji kecantikan jasmani si gadis Sulam, dan juga kecantikan rohaninya (inner beauty) yang terpancar dari tatapan matanya. "Bagaikan merpati matamu" merujuk pada sorotan mata si gadis Sulam yang jernih, tulus, murni, tanpa pamrih, tidak bercacat-cela bagaikan mulusnya seekor merpati. Si gadis Sulam pun ganti memuji sang gembala, kekasihnya: "Lihatlah, tampan engkau, kekasihku, sungguh menarik; sungguh sejuk petiduran kita. Dari kayu aras balok-balok rumah kita, dari kayu eru papan dinding-dinding kita" (Kid 1:16-17).

Pohon aras banyak tumbuh di daerah Libanon. Kayunya yang pahit dan keras disingkiri serangga, sehingga tidak gampang lapuk, tahan lama dan cocok untuk balok-balok rumah. Kayu eru sejenis bambu yang bisa dibelah-belah dan dianyam untuk dinding rumah. $\mathrm{Si}$ gadis Sulam memuji ketampanan jasmani sang gembala, dan juga ketampanan rohaninya yang terpancar dalam kerja kerasnya membangun rumah tinggal idaman. Lagi-lagi sang gembala balik memuji si gadis Sulam: "Seperti bunga bakung di antara duri-duri, demikianlah manisku di antara gadis-gadis" (Kid 2:2).

Bunga bakung banyak tumbuh di Palestina, terutama di daerah pantai yang membentang dari Kaisarea hingga Yope. Mungkin bunga bakung lembah itu berwarna merah, karena sebanding dengan bibir merah si gadis Sulam. Rabbi Eliezer mengatakan: "Orang benar harus disamakan dengan bunga bakung lembah yang terus berkembang, dan bukan bunga bakung gunung yang cepat layu." Dengan demikian secara alegoris si gadis Sulam yang seperti bunga bakung itu mau menganalogikan bahwa Gereja umat Allah harus lebih mengutamakan dan mengembangkan keutamaan-keutamaan/harta rohani yang lebih berharga dan bersifat kekal (bdk. Mat 6:28-33).

Gereja umat Allah yang riskan terhadap godaan-godaan harta dunia itu digambarkan dengan "bunga bakung di antara duri-duri". Rujukannya adalah si gadis Sulam yang telah dibawa Raja Salomo ke istananya dan berada di antara puteri-puteri Yerusalem dan isteri-isteri raja. Oleh karena itu, si gadis Sulam harus hati-hati dan terus waspada kalau-kalau duri-duri itu menusuknya atau puteri-puteri Yerusalem dan isteri-isteri raja itu membujuk dan memaksanya untuk menerima cinta dan menjadi kekasih Raja Salomo. Ia harus waspada terhadap godaan mereka yang mungkin saja dapat memisahkan cinta pertamanya dengan 
si gembala. Bukankah Raja Solomo akhirnya jatuh dari keagungannya dan menjadi penyembah berhala karena ulah isteri-isterinya?

Setia pada cinta pertama dan selalu waspada terhadap godaan yang dapat memisahkan dari Kristus adalah sikap hidup yang harus dipilih oleh Gereja umat Allah. Gereja harus selalu waspada sampai pada hari kedatangan Kristus kembali yang akan menghancurkan puteri-puteri Yerusalem atau orang-orang yang tidak mau bertobat dan menolak-Nya (bdk. Mat 12:39-42).

$\mathrm{Si}$ gadis sulam menanggapi pujian dan cinta sang gembala dengan memegang setia cinta pertama kepadanya: "Kusumpahi kamu, puteri-puteri Yerusalem, demi kijang-kijang atau demi rusa-rusa betina di padang: jangan kamu membangkitkan dan menggerakkan cinta sebelum diingininya!" (Kid 2:7). Si gadis Sulam meminta agar puteriputeri Yerusalem berhenti menggoda dan membujuknya untuk menerima cinta Raja Salomo. Ia telah jatuh cinta kepada sang gembala dan tidak mau menukar kekasihnya itu dengan orang lain (Raja Salomo). Maka, agar berhenti menggodanya, si gadis Sulam pun terpaksa menyumpai mereka. Sumpah bukan sekedar perintah atau kata-kata, tetapi pada zaman kuno dulu selalu diucapkan demi nama dewa-dewi atau di kalangan orang Israel demi nama TUHAN Allah mereka satu-satunya. Dengan sumpah berarti orang mau mempertanggungjawabkan benar-tidaknya perkataannya bukan hanya di hadapan manusia tetapi bahkan di hadapan yang ilahi.

Sumpah dan larangan agar "jangan kamu membangkitkan dan menggerakkan cinta sebelum diingininya" berkaitan dengan godaan untuk membangkitkan cinta palsu, yaitu cinta karena harta, kuasa, terpaksa atau takut. Sebab cinta sejati tidak perlu dipaksa-paksa bangkit dari luar diri. Cinta sejati muncul dari dalam diri sama bebasnya dan tidak terikat seperti bebasnya gerak lincah-cekatan kijang-kijang dan rusa-rusa betina. Rujukan sumpah "demi kijang-kijang atau rusa-rusa betina di padang" mengacu pada simbol-simbol keanggunan dan kecantikan yang lazim di Lebanon. Dengan demikian cinta sejati tidak dapat dipaksa-paksa dan justru dalam kebebasannya akan nampak anggun dan indahnya.

Cinta si gadis Sulam kepada sang gembala adalah cinta sejati. Ia menepis godaan Raja Solomo dan tetap bertahan pada cinta pertamanya, yaitu sang gembala. Hal ini secara alegoris mau menganalogikan Gereja umat Allah yang harus tetap setia pada Kristus Sang Mempelai Laki-lakinya atau TUHAN Allah mereka satu-satunya. 
Penulis surat kepada jemaat di Efesus mencatat: “Aku mencela engkau, karena engkau telah meninggalkan kasihmu yang semula" (Why 2:4).

Adat pertunangan dalam struktur patriarkhal pun mengesahkan bahwa suami adalah pemilik penuh atas isterinya, sehingga berkuasa penuh atas isterinya dan tidak sebaliknya. Buku Kidung Agung menegaskan bahwa suami-isteri yang sah sejak pertunangannya adalah pasangan yang saling memiliki satu sama lain: "Kekasihku kepunyaanku, dan aku kepunyaan dia [...] Kepunyaan kekasihku aku, kepadaku gairahnya tertuju. Mari, kekasihku, kita pergi ke padang, bermalam di antara bunga-bunga pacar!" (Kid 2:16; 7:10-11).

Gadis Sulam menegaskan bahwa dirinya telah menjadi milik sang gembala dan sebaliknya sang gembala adalah miliknya. Gairah cinta sang gembala yang sudah menjadi miliknya itu selalu tertuju kepadanya yang juga milik sang gembala. Karena mereka telah samasama memiliki satu sama lain, maka mereka bisa dan boleh pergi bersama ke padang dan bermalam di antara bunga-bunga pacar. Dari kata Ibraninya, kep $\square$ arîm berarti bunga-bunga pacar, tetapi kap $\square \bar{a} r$ juga dapat diartikan dengan sebuah kampung yang tertutup atau dibentengi tembok. Dari kata Ibrani itu muncul arti kiasannya, yaitu bunga pacar, uang sogok atau uang tebusan. Oleh karena itu, pergi ke padang di antara bunga-bunga pacar mau menganalogikan Gereja umat Allah yang telah ditebus oleh Kristus dengan darah-Nya sehingga telah menjadi milik-Nya.

Buku Kidung Agung pun berbicara tentang seksualitas laki-laki dan perempuan yang bukan demi pemuasan nafsu birahi dan kepuasan diri, tetapi karena cinta sejati yang tidak dapat dibeli dan yang dibawa mati. Cinta sejati laki-laki dan perempuan itu dijadikan analogi hubungan cinta Allah dengan umat pilihan-Nya (tafsir Yahudi) atau hubungan cinta Kristus dengan Gereja-Nya (tafsir Kristen).

Buku Kidung Agung melukiskan kisah kasih sepasang manusia yang saling jatuh cinta, yaitu si gadis Sulam dan sang gembala. Si gadis Sulam meminta kepada sang gembala, kekasihnya: "Taruhlah aku seperti meterai pada hatimu, seperti meterai pada lenganmu" (Kid 8:6a). Meterai berfungsi untuk menjaga kerahasiaan dan bermakna kepemilikan kekal. Permintaan si gadis Sulam agar memeteraikan dirinya berarti permintaan untuk menjadikan dirinya milik sang gembala selama-lamanya dan personal/rahasia.

Si gadis Sulam itu meminta dirinya dimeteraikan dalam hati dan lengan sang gembala, karena ia sedang berada di istana raja dan 
dibujuk-rayu oleh puteri-puteri Yerusalem untuk menerima cinta Raja Salomo. Ia sedang menghadapi godaan yang memungkinkan kehilangan sang gembala, kekasihnya. Oleh karena itu, ia meminta agar dirinya dimeteraikan, sehingga ia berkeyakinan telah menjadi milik sang gembala untuk selama-lamanya dan dapat mengatasi godaan. Keyakinan bahwa "dirinya sudah ada yang punya" akan membantunya dalam menolak bujuk-rayu cinta sang raja.

Pembaptisan umat Allah dalam nama Yesus kiranya menjadi acuan dari pemeteraian diri si gadis Sulam. Pembaptisan dalam nama Yesus adalah pemeteraian yang membuat seorang beriman menjadi milik Allah: "Di dalam Dia kamu juga, ketika kamu percaya, dimeteraikan dengan Roh Kudus, yang dijanjikan-Nya itu. Dan Roh Kudus itu adalah jaminan bagian kita sampai kita memperoleh seluruhnya, yaitu penebusan yang menjadikan kita milik Allah, untuk memuji kemuliaan-Nya" (Ef 1:13-14). Selalu sadar bahwa dirinya telah menjadi milik Allah dapat membantu dalam menghadapi tawaran, godaan dan bujuk-rayu si jahat.

Si gadis Sulam meminta agar dirinya dimeteraikan dalam hati dan lengan. Dimeteraikan di hati berarti merujuk pada bagian diri yang internal dan personal, sehingga sangat rahasia. Sedangkan dimeteraikan di lengan berarti merujuk pada bagian diri yang eksternal, sehingga terbuka dan dapat diketahui masyarakat luas. Cinta sejati bersifat kekal dan memiliki dimensi internal dan eksternal. Cinta yang hanya berdimensi internal menjadi cinta yang misterius dan tertutup rapat, sehingga lepas dari pengamatan, pengakuan dan kontrol publik. Sebaliknya cinta yang hanya berdimensi eksternal menjadi sangat dangkal, karena tidak didasari oleh kasih yang berakar di hati.

Dimensi eksternal dari cinta nampak jelas dalam liturgi pemberkatan pernikahan, di mana kedua mempelai saling menyatakan janji setia dan mengenakan cincin yang disatukan dengan formula peneguhan dan pemberkatan atas nama Allah. Namun semua itu dapat terjadi karena kedua mempelai telah menjalin komitmen untuk saling mencintai dari lubuk hati mereka yang terdalam. Jadi, dalam peneguhan dan pemberkatan pernikahan nampak kesatuan dimensi eksternal dan internal, yaitu peneguhkan komitmen dan janji untuk saling mencintai dengan kesetiaan kekal. Oleh karena itu, hanya kematian atau maut yang dapat memisahkan hubungan suami-isteri. Cinta yang dimeteraikan di hati dan lengan berdimensi internal dan eksternal, sehingga bersifat kekal dan hanya dapat dipisahkan oleh kematian. 
Dalam pandangan umum bangsa Israel, kematian memang memisahkan dan mengakhiri hubungan antara orang hidup dan orang mati, karena orang mati akan masuk ke syeol atau dunia orang mati. Namun bagi si gadis Sulam, kematian pun tidak mampu memutuskan cintanya yang sejati: "Karena cinta kuat seperti maut, kegairahan gigih seperti dunia orang mati" (Kid 8:6b).

Ungkapan "maut" dan "dunia orang mati" (syeol) bermakna teologis, yaitu keadaan yang serba kelam dan terputusnya hubungan total dengan orang-orang hidup. Orang yang mati dan masuk dunia orang mati akan mengalami putus hubungan dan terpisah dari orangorang di dunia orang hidup. Namun keadaan yang sangat negatif itu dibalik dan dimaknai secara positif oleh si gadis Sulam. Kematian tidak kuasa memutuskan cinta dan cinta sejati tidak pernah akan lenyap meskipun salah satu dari mereka sudah berada di dunia orang mati. Secara jasmani, kematian memang memisahkan dua orang yang saling mencintai, tetapi sesungguhnya cinta mereka berdua tetap terjalin dan tidak pernah berakhir. Cinta sejati bersifat kekal dan tidak kenal batas. Cinta sejati mampu menembus batas-batas dunia dan tidak terbelenggu oleh kefanaan hidup. Cinta sejati adalah cinta dengan kegairahan dan kecemburuan yang kudus. Artinya, tidak ada tempat bagi orang lain untuk masuk dalam rumah tangga mereka, karena mereka saling mencemburui dan mencintai dengan sepenuh hati.

Beberapa ahli Kitab Suci menganalisis dan mengatakan bahwa nama Raja Salomo (laki-laki) dan si gadis Sulam (perempuan) merujuk pada realita maskulin dan feminim dari manusia. Sebab nama Salomo dan Sulam berasal dari akar kata Ibrani yang sama, yaitu slm. Akar kata slm merujuk pada kata syalom yang berarti "damai sejahtera". Jadi, nama Sulam adalah bentuk feminim dari nama maskulin Salomo. Bila aspek feminim dan maskulin itu terjalin hubungan yang harmonis dan saling mencintai, maka terciptalah damai sejahtera dari Allah. Jika laki-laki dan perempuan menjalin cinta yang dimeteraikan secara kekal di hati dan di lengan mereka, maka mereka akan mengalami damai sejahtera ilahi. Jalinan cinta yang demikian menjadi kekal dan tidak akan terputuskan oleh kekuatan apapun: "Nyalanya adalah nyala api, seperti nyala api Tuhan. Air yang banyak tak dapat memadamkan cinta, sungai-sungai tak dapat menghanyutkannya" (Kid 8:6c).

Pada umumnya api bisa dipadamkan dengan air, tetapi api cinta sejati dari pasangan yang saling mencintai dan berjanji tetap setia akan terus bernyala dan tidak dapat dipadamkan oleh air yang banyak, bahkan sungai-sungai sekalipun. Sebab nyala api cinta mereka 
dikobarkan oleh api cinta ilahi, sehingga terus bernyala selama-lamanya hingga menembus batas-batas kematian jasmani. Oleh karena itu, makna cinta sejati dalam buku Kidung Agung dipakai untuk menganalogikan hubungan cinta Allah dengan umat pilihan-Nya atau hubungan cinta Kristus dengan Gereja-Nya. Allah atau Kristus digambarkan sebagai pribadi yang maskulin dan umat pilihan-Nya atau Gereja-Nya feminin.

Cinta sejati dibawa mati dan tidak dapat dibeli atau ditukar dengan harta benda: "Sekalipun orang memberi segala harta benda rumahnya untuk cinta, namun ia pasti akan dihina" (Kid 8:7). Usaha Raja Salomo untuk membeli cinta si gadis Sulam dengan segala kemewahan harta kekayaan istananya berakhir dengan kegagalan. Cinta sejati tidak mungkin dipadamkan, termasuk oleh permasalahan hidup yang berat (godaan/tawaran kuasa dan harta kekayaan). Cinta sejati mampu menghadapi ujian terberat sekalipun (kematian).

Cinta sejati si gadis Sulam menjadi analogi cinta sejati umat pilihan Allah dan iman akan TUHAN Allah mereka satu-satunya yang dipertahankan hingga mati sebagai martir. Kisah tujuh orang bersaudara serta ibunya yang disengsarakan dalam 2Mak 7:1-42 melukiskan bahwa cinta dan iman mereka akan TUHAN Allah tidak dapat dibeli dengan harta dan kekuasaan.

Cinta sejati si gadis Sulam menjadi analogi cinta sejati dan iman Gereja yang tidak tergadaikan oleh harta dan kuasa duniawi. Penulis surat kepada jemaat di Efesus mencatat: "Aku mencela engkau, karena engkau telah meninggalkan kasihmu yang semula" (Why 2:4). Kepada setiap orang yang mau mengikuti-Nya Yesus berkata: "Barangsiapa mau menyelamatkan nyawanya, ia akan kehilangan nyawanya; tetapi barangsiapa kehilangan nyawanya karena $\mathrm{Aku}$, ia akan memperolehnya. Apa gunanya seorang memperoleh seluruh dunia tetapi kehilangan nyawanya? Dan apakah yang dapat diberikannya sebagai ganti nyawanya?" (Mat 16:25-26).

Buku Kidung Agung mengangkat derajat seorang perempuan di kalangan bangsa Israel yang berstruktur patriarkhal dengan menyejajarkan derajat dan menganalogikan hubungan suami-isteri sebagai hubungan Allah-Israel. Buku Amsal dan Yesus bin Sirakh pun mengisahkan pujian yang mengangkat derajat seorang perempuan dan isteri: "Siapa mendapat isteri, mendapat sesuatu yang baik, dan ia dikenan TUHAN" (Ams 18:22); "Rumah dan harta adalah warisan 
nenek moyang, tetapi isteri yang berakal budi adalah karunia TUHAN" (Ams 19:14); "Karunia berlipat dualah seorang isteri yang sopan, dan perempuan murni tidak ada imbangannya" (Sir 26:15). Sir 26:1-3,13-18 dan Ams 31:10-31 juga menyajikan madah pujian tentang keunggulan dan peran seorang isteri yang baik, berbudi, sopan dan cakap:44

26:1Berbahagialah suami dari isteri yang baik, dan panjang umurnya akan berlipat ganda. ${ }^{2}$ Isteri berbudi menggembirakan suaminya, yang dengan tenteram akan menggenapi umurnya. ${ }^{3}$ Isteri yang baik adalah bagian yang baik, yang dianugerahkan kepada orang yang takut akan TUHAN. ${ }^{13}$ Keelokan isteri menyenangkan suaminya, tetapi kepandaiannya membesarkan hatinya [...] ${ }^{15}$ Karunia berlipat dualah seorang isteri yang sopan, dan perempuan murni tidak ada imbangannya. 16Laksana matahari yang terbit di atas pegunungan Tuhan, demikianlah keelokan isteri baik di tengah rumah tangga yang rapih [...].

36:21Seorang perempuan menerima suami mana pun, tetapi anak perempuan yang satu adalah lebih baik dari yang lain [...] ${ }^{24}$ Barangsiapa mendapat isteri memperoleh milik yang unggul, seorang pembantu yang serasi dengannya dan sebuah tiang penyangga.

31:10Isteri yang cakap siapakah akan mendapatkannya? Ia lebih berharga dari pada permata. ${ }^{11}$ Hati suaminya percaya kepadanya, suaminya tidak akan kekurangan keuntungan. ${ }^{12} \mathrm{Ia}$ berbuat baik kepada suaminya dan tidak berbuat jahat sepanjang umurnya [...] ${ }^{30}$ Kemolekan adalah bohong dan kecantikan adalah sia-sia, tetapi isteri yang takut akan TUHAN dipuji-puji [...].

Ungkapan "isteri yang cakap" merujuk pada kata Ibrani 'ēše $\square$ $\square$ ayil, yaitu seorang perempuan yang memiliki kekuatan, kemampuan, kecakapan, ketrampilan. Kekuatan dan kecakapan itu berkaitan dengan dunia militer maupun ekonomi. Dalam Kitab Suci kekuatan dan

${ }^{44}$ P. Dacquino, Storia..., hlm. 61; L.A. Schökel, I Nomi..., hlm. 277-278; W. McKane, Proverbs. A Commentary, OTL (London: SCM Press, 1970), hlm. 665670. Analisis mendalam tentang Ams 31:10-31 dapat dibaca pada kedua artikel berikut: T.P. McCreesh, "Wisdom as Wife: Prv 31,1.10-31", dalam Revue Biblique, 92 (1985), hlm. 25-45; A. Bonora, "La donna eccellente, la Sapienza, il Sapiente (Pr 31,10-31)", dalam Rivista Biblica Italiana, 36 (1988), hlm. 137-163. 
kecakapan seperti itu hampir selalu diperuntukkan bagi kaum laki-laki. Oleh karena itu, isteri yang cakap adalah isteri yang memiliki kekuatan, kemampuan, ketrampilan dan kecakapan dalam segala hal yang berhubungan dengan tugasnya sebagai ibu rumah tangga. Kekuatan dan kecakapan seperti itu bila dibandingkan dengan permata jelas jauh lebih berharga. 45

Isteri yang cakap, berbudi, baik dan sopan dapat berbuat baik kepada suami seumur hidupnya bukan karena ia mampu memelihara daya tarik tubuhnya, tetapi karena ia takut akan TUHAN. Pengakuan, hormat dan kepercayaannya kepada TUHAN menjadi sumber kekuatan, kecakapan, kebaikan, dan kesopanannya serta penyebab segala pujian baginya. Dengan demikian patokan umum untuk menilai seorang isteri adalah: a) bukan kecantikan yang menjadi ukurannya, tetapi sikap takwanya yang takut akan TUHAN, karena kecantikan hanyalah kepalsuan yang tidak berguna; b) kekuatan, kecakapan, kebaikan, kesopanan dan keberbudiannya yang membuat dirinya sukses dalam menjalankan tugasnya sebagai ibu rumah tangga. Singkat kata, nilai seorang isteri ditentukan oleh TUHAN dan terletak dalam sikap takwanya serta ditentukan oleh masyarakat dan terletak dalam kecakapan dan keberhasilannya sebagai ibu rumah tangga. ${ }^{46}$

Ams 31:10-31 dan Sir 26:1-3,13-18 menyajikan madah pujian tentang keunggulan nilai seorang isteri yang selama hidupnya hanya menginginkan kebaikan semata dan membahagiakan (menguntungkan, dipercayai) suaminya. Meskipun demikian madah tersebut tetap memperlihatkan sudut pandang dari kaca mata kaum laki-laki, yaitu nilai tertinggi dari seorang perempuan (isteri) seolah-olah tetap pada peranannya sebagai "penolong bagi laki-laki, pembantu yang serasi dan tiang penyangga baginya": berbuat baik dan tidak jahat kepada suaminya seumur hidupnya, sehingga suaminya percaya kepadanya dan tidak kekurangan keuntungan. Sebaliknya isteri yang jahat akan mencelakakan suaminya: "Isteri yang cakap adalah mahkota suaminya, tetapi yang membuat malu adalah seperti penyakit yang membusukkan tulang suaminya" (Ams 12:4); "Lebih aku suka berumah bersama singa dan naga dari pada bersama dengan isteri yang jahat. Kejahatan perempuan mengubah roman mukanya, dan menyuramkan air

${ }^{45}$ M. Harun, Marilah, Makanlah Hidanganku... Hikmat Israel dalam Amsal, Ayub \& Pengkhotbah (Jakarta: LAI, 2010), hlm. 51.

${ }^{46}$ W. van der Weiden, Seni Hidup. Sastra Kebijaksanaan Perjanjian Lama (Yogyakarta: Kanisius, 1995), hlm. 73; M. Harun, Marilah..., hlm. 53. 
mukanya seolah-olah beruang betina. Suaminya duduk makan di tengah-tengah kawannya, dan mau tidak mau mesti mengeluh dengan pahitnya" (Sir 25:16-18). ${ }^{47}$

Madah pujian tentang isteri yang cakap-baik-sopan-berbudi dalam buku Amsal dan Yesus bin Sirakh serta analogi hubungan AllahIsrael dengan suami-istri dalam buku Kidung Agung mau menggugat dan mengoreksi anggapan masyarakat patriarkhal yang bias gender, di mana kekuatan, kecakapan, kebaikan, kesopanan dan keberbudian hanya milik kaum laki-laki, sementara kaum perempuan itu lemah dan bodoh sehingga harus dilindungi. Dengan analogi hubungan suamiisteri dan madah pujian tentang isteri yang cakap, baik, sopan dan berbudi karena hikmat kebijaksanaannya yang berakar pada iman dan sikapnya yang takut akan TUHAN, Kitab Kidung Agung, Amsal dan Yesus bin Sirakh mau menyatakan bahwa Kitab Suci tidak mengajarkan bias gender, tetapi sebaliknya justru menegaskan kesetaraan antara lakilaki dan perempuan dalam hal kekuatan dan kecakapan. Keduanya dapat memberi sumbangan yang sama-sama substansial dalam membangun kesejahteraan baik di keluarga maupun di masyarakat.

\section{Kesimpulan}

Kitab Suci Perjanjian Lama memaparkan sangat banyak dan tersebar di berbagai buku (Taurat Musa, Nabi-nabi dan Hikmat Kebijaksanaan) signal-signal tentang seksualitas dan lembaga

${ }^{47}$ Bdk. "Kejahatan laki-laki lebih baik dari pada kebajikan perempuan, dan perempuanlah yang mendatangkan malu dan nista!” (Sir 42:14); “Dan aku menemukan sesuatu yang lebih pahit dari pada maut: perempuan yang adalah jala, yang hatinya adalah jerat dan tangannya adalah belenggu [...]" (Pkh 7:26). Memang ayat-ayat ini sungguh melecehkan keberadaan kaum perempuan. Pandangan negatif terhadap kaum perempuan ini bukan karena Yesus bin Sirakh dan Pengkhotbah punya pengalaman negatif atau anti wanita, tetapi begitulah trend dalam Sastra Kebijaksanaan Israel dan dunia Israel waktu itu yang berstruktur patriarkhal-patrilineal. Di seluruh wilayah Timur Tengah, Sastra Kebijaksanaan berasal dari dunia yg eksklusif maskulin. Oleh karena itu, tidak ada perhatian terhadap kaum perempuan dan kalau kaum itu disinggung, maka sudut pandangnya pasti dari kaum laki2. Maka, kalau ada seorang isteri yang cakap, baik, sopan dan berbudi, pujian ditujukan bukan kepada dirinya tetapi kepada suaminya sebagai orang yang mendapat karunia dari Allah. 
perkawinan yang menampungnya. Dua versi kisah penciptaan dalam Kej 1-2 secara tidak langsung berbicara tentang lembaga perkawinan yang mengatur seksualitas. Dalam Buku Taurat Musa lembaga perkawinan itu dipandang sebagai kontrak sipil dengan peran mas kawin, tahap-tahap perkawinan dan sifatnya endogen poligam poligini. Dalam Buku Nabi-nabi lembaga perkawinan dijadikan analogi hubungan Allah dengan bangsa Israel. Dalam Buku Hikmat Kebijaksanaan analogi hubungan Allah-Israel dengan suami-isteri diteruskan, kesetaraan derajat laki-laki dan perempuan dijunjung tinggi, dan seksualitas dipandang positif serta seorang isteri yang berbudi, sopan dan cakap dipuji-puji.

$====0000====$ 
Surip Stanislaus, Perkawinan dalam Kitab Suci Perjanjian Lama

\section{DAFTAR PUSTAKA}

Dacquino, P. Storia del Matrimonio Cristiano alla Luce della Bibbia. Torino: Elle Di Ci, 1984.

de Vaux, R. Ancient Israel. Its Life and Institutions. London: Darton, Logman \& Todd, 1962.

Groenen, C. Perkawinan Sakramental. Anthropologi dan Sejarah Teologi, Sistematik, Spiritualitas, Pastoral. Yogyakarta: Kanisius 1993.

Schökel, L.A. I Nomi dell'Amore. Simboli Matrimoniali nella Bibbia. Casale Monferrato: Piemme, 1997.

Wenham, G.J. Genesis 1-15, WBC 1. Nashville: Thomas Nelson Publisher, 1987.

Yasua, P. Perempuan Sumber Dosa? Sebuah Refleksi Alkitabiah. Malang: Dioma, 2011. 